\title{
The Impact of Toondoo Comics on Undergraduate Students Taking Creative Writing and Children Literature Courses at the Lebanese University Faculty of Pedagogy
}

\author{
Mona Tahsaldar ${ }^{1}$, Charbel Semaan ${ }^{2}$ \\ ${ }^{I}$ Associate Professor in English Education \\ ${ }^{2}$ Assistant Professor in Technology in Education
}

\begin{abstract}
Technology is now an important aspect for university student learning experience. Academic research has focused on the potentials of technology in enhancing student learning and motivation to develop their creative writing skills. This research explores students' actual experience in using technology in their university classes which made it a case of integrating Toondoo Comics in Creative Writing and Children Literature courses. Thus, this paper investigates the effect of Toondoo Comics on university students' creative writing skills, their motivation and attitudes toward creative writing and Children Literature courses.

Participants were_14 second and third year student teachers at the Lebanese university faculty of pedagogy branch two during the academic year 2017-2018. As creative writing increases students' enthusiasm to develop their writing skills and the rise of using technology in the field of education, the participants were taking the Creative Writing and Children Literature courses, in a series of assignments using Toondoo Comics. Data were collected through pre-post questionnaires, observation of discussions, and assignments and presentations held in class. Results show that there is a significant difference favoring the implementation of Toondoo in university classes, and that Toondoo Comics improves the students' creative writing skills and motivates them to be involved in the university courses.
\end{abstract}

Keywords: creative writing, children literature, creative courses, Toondoo comics, motivation, attitude, technology in education

\section{INTRODUCTION}

It is argued that learning based on the classroom, lecture hall and other traditional learning environments is outdated and extremely limited for the acquisition of knowledge and skills. Gravels (2011) found that teaching to pass tests does not develop the learner's abilities and potentials. Based on more than 20 years of monitored research conducted by the International Society for Technology (ISTE) in Education, the State Educational Technology Directors Association (SETDA), and the Partnership for 21st Century Skills (2008), findings reveal that there is one convincing trend that has positive effects on students' achievement and can be considered a platform to improve students' critical thinking abilities and to address their challenges and attitudes. It is the integration of technology in both teaching and learning processes. Many educators found that using ICT movies and Comics, are beneficial educational tools to motivate and encourage students to activate their thinking and carry out the development of English language activities (Silva, et al. 2012; Anastasiou, et al., 2004; Wood, 2008; Oliveira, 2014). Accordingly, Li (2012) stated that students who have a positive attitude towards their academic endeavor tend to perform well academically. Thus, motivation and attitude are significant predictors of students' academic development.

As latest technology tools boom, it is vital that teachers integrate these tools into the classroom activities to improve the teaching-learning process. Technology to Ochoa and Holguin (2013) resembled through Web 2.0 Toon Doo Comics offered diverse visions to advance students' learning to become critical thinkers, as it helped them express sound, music, words, pictures, images and texts. Objectively, to Ochoa and Holguin (2013) the implementation of Web 2.0 Toon Doo Comics as a pedagogical tool helped students to come up with attractive pieces of literature that could be published. Recognizing the significance of this matter, we as members of the Lebanese university faculty of pedagogy English language staff who were seeking actual, innovative and effective strategies that help students overcome their learning difficulties and lack of interest to write creatively planned to investigate the effect of this tool on students at the faculty of pedagogy. 
In short, our concern in this study is to examine the effects of integrating Toondoo Comics in Creative writing and Children Literature courses on the Lebanese university faculty of pedagogy student teachers' motivation to write creatively and their creative writing skills. As an Educational Technology assistant professor and an associate professor in English education at the Lebanese university faculty of pedagogy who has been teaching the mentioned courses for many years, have worked hard so that students could achieve the objectives of these courses and write creative poems and stories.

\section{Problem Statement}

The unceasing technology advancement pushed various universities to employ innovative strategies and technology integration to develop productive competitive students well equipped with technological competence. In the same sense, Silva (2014) claimed that setting organized and actionoriented activities could be a guide to achieve the educational goals and to satisfy students' needs. Santos (2013) shows that the lack of students' interest during the process of managing education is an obstacle to achieve the professional educational development. Similarly, Ramos (2005) reveals the importance of involving new strategies and new technology tools in handling the formation of students as citizens of a modern and multicultural society. Thus, to create a learning environment that stimulates undergraduate students to become active learners Silva et al. (2012), Masetto (2012) and Lima et al. (2014) found that active learning environment should be guided by a professor who adopts new technologies that promote better learning. Although using technology tools in teaching and learning is flourishing and reached the peak in now a day education to help students approach knowledge, we found that the educational system in Lebanon is still suffering from the poor usage of technology in classes as a result of many political economy and social issues.

Traditionally, the teaching of Children Literature and Creative Writing courses at the Lebanese university faculty of pedagogy has been practiced as teaching of structures without real communicative function which requires a change. Moreover, the call of the ministry of higher education with the help of the Lebanese university central administration is to graduate student teachers capable of teaching English language skills with comparable international standards that involve the country in the global education, motivated the researchers to look for updated techniques that encourage students to work in an updated learning environment.

Similar to Brown (2007), the English as Foreign Language (EFL) writing skill for the Lebanese University faculty of pedagogy students is a basic skill since it reflects their development in the four skills of EFL.

When checking the methodology used in English classes at the Lebanese university faculty of pedagogy, we could identify some strengths when using multimodal tools such as reading and analyzing literature genres, presentations etcetera, but for weaknesses, we could identify the few uses of technology tools since the university does not afford a public internet for students and teachers. As an associate professor who has been teaching creative writing and Children Literature courses for several years, it was obvious to realize that many of the students' written productions were ignored and wasted after being graded which lead students to feel demotivated and frustrated. Unfortunately, all what students have written through past years was not recognized or taken into account although they worked hard and their written productions can be considered worth to be taken into consideration. Furthermore, many of our students suffer from their primary EFL levels specially when the course is minor for them and the environment they live in does not allow English language practice. As a result, one of the biggest challenges for us as university teachers was the lack of updated solutions to satisfy students' needs and develop their writing skills, motivate them to write creative poems and stories and document their literature productions. Therefore, as an English associate professor and an IT assistant professor at this faculty, we questioned ourselves about the most possible solutions that help students develop their creative writing and be motivated as well as involved in the mentioned courses so that their written productions will not be misused, wasted or ignored after being graded.

It was not an easy task for us as university professors to find updated ways suitable for the Lebanese university environment, help students develop their creative writing skills and motivate them to write their assignments, without integrating Toondoo Comics that facilitated considering students' 
assignments proper to be documented. Worth to be mentioned that the idea of this study was shared by Dr. Charbel Samaan, a technology in education assistant professor at the Lebanese university faculty of Pedagogy, who suggested Toondoo Comics to be integrated in the Children Literature and Creative Writing courses where students can choose characters, pictures and background suitable for the elements of their written stories and poems. Fortunately, the idea was a remedy for all what was happening with our students, during previous years, from demotivation to their ignored literature productions. Thus, as people of research we had to examine the effects of this technology tool on students' written productions and their motivation and attitude before and after integrating Toondoo Comics in the two courses.

\section{Study Questions}

The study was guided by the following main question:

What are the effects of using Toondoo Comics on university students' creative writing activities and their attitude toward teaching creative writing courses using Toondoo?

More questions derived from the main question:

1-What is the level of improvement in students' EFL writing skills after taking the course?

2-Which of the practiced writing strategies helped students develop their written poems and stories?

3-What are the differences between students creative writing skills before and after taking the two courses presented in the results of the pre and post questionnaires?

4-what is the degree of differences_between students' attitudes and motivation toward creative writing before and after implementing Toondoo tool in Children Literature and Creative Writing courses?

5- To what extent does Toondoo help elaborate students' written pieces of literature?

\section{Purpose of the Study}

This study aims to determine the effects of integrating Toondoo Comics on students' written productions and their attitudes toward using technology in Children Literature and Creative Writing courses.

The purpose of this study is to investigate the effects of integrating Toondoo Comics in Children Literature and Creative Writing courses on student teachers' written productions and their attitudes and motivation toward these courses. Thus, it highlights the students-teachers' reactions toward technology integration in teaching and learning as well as their abilities to modify their writing skills. Accordingly, the study examined the extent of importance Toondoo technology plays in teaching Creative Writing and Children Literature courses and the level of interest it raises in university student teachers to write their literature productions. Investigating the effect of Toondoo Comics on student teachers motivation to write poems, stories, and their creativity in writing their stories and poems are the main objectives of this study.

\section{Study Significance}

This study significance is for those who are willing to transform their pedagogic practice into new updated technology resources. Using Toondoo Comics employs new roles oriented towards students and teachers' personal expressions, and ultimately teaching and learning. Thus, the knowledge that can be acquired from this study is for the benefit of both teachers and students. Moreover, this study results can offer an insight to develop Children Literature and Creative Writing courses curricula, increase student engagement and participation as well as motivate them to develop their creative writing competences. Finally, this research is not only a valuable resource for university professors and students but also for all teachers of other courses in different stages as it adds a significant contribution to the existing body of education??

\section{LITERATURE REVIEW}

Using Expressive and Creative Forms of Writing with Learners witnessed a growing popularity in recent years. Highlighting the role of creative writing, Bilton and Sivasubramaniam (2009) realized that education focused on students' occupational needs forgetting about their emotional needs. As a result, they suggested adding more creative writing activities to the curriculum so that students can enhance their creative skills that are fundamental in education. Accordingly, James (2009) and Harper 
\& Kroll (2008) found that many institutes offered Creative Writing Courses to achieve developing creativity in students. Hence according to Dudek (2003), creativity plays an important role in technological advance, and in all majors specifically in education. Similarly, creative writing is an important contribution to the development of many language skills and a tool to express student's feelings, thoughts and information in an interesting way that should not be only evaluated as a mechanical process but as a skill that reflects the level of understanding, thinking, developing and producing (Larkin, 2009). Accordingly, Maley (2012) identifies creative writers as learners who are able to manipulate the language in interesting ways to express uniquely personal meanings, and engage with the language at a deeper level of processing, which leads to significant gains in grammatical accuracy and originality of lexical choice. Moreover, Oral (2012) claimes that creative writing is expressing one's ideas and feelings about a particular topic freely, while Mone (2011) finds that becoming creative writers requires planning, developing ideas, supporting details, reflecting and evaluating the written productions. Contradicting most of the approaches used to develop students' creative writing skills Donovan (2008) and Haven (1999) claim that creativity is a non-teachable art form.

Concerning the benefits of creative writing activities, Stillar (2013) reveals that students' engagement in creative writing activities helps them experience higher levels of enthusiasm and motivation that are reflected in their enhanced writing abilities and their free imagination employment. Moreover, Cook, (2000) finds that creative writing fosters students to discover things not only about the language but about themselves as well. He adds that creative writing feeds from creative reading and the development of the aesthetic reading skills, that provide the learner with a better understanding of textual construction that contributes to expressing their feelings and awareness in their writing.

In order to motivate learners to become creative writers, Brookes \& Marshall (2004) find that creative writing tasks are motivating for students (as cited in Temizka, 2011). For instance, Vanderslice (2011) noted in the introduction of her book that the importance of creative writing pedagogy lies in motivating and improving the writing experience of students. Accordingly, teaching creative writing to Barbot, et al (2012) is encouraging students to write by transferring their imagination into written expression.

Similar to many authors, creative activities ended up with many creative literature productions written by students; for example, Lee (2012) implemented the electronic reading response journal, in which the students expressed their reactions and emotions in different literary texts that showed great levels of engagement with the assignment and posted poems, stories and other forms of creative writing. In the same sense, Demir (2013) found that students' creativity was reflected through their written productions where their creative thinking was derived from the new acquired information merged with their prior knowledge to come up with new ideas. In accordance with our study aims, Mayers' (2009) mentions that the rationale behind creative pedagogy is to introduce changes in the function of creative writing as an academic enterprise not just to produce writers, but to promote the intellectual framework of literacy itself and expand creative writing theories to practical knowledge of stories, poetry, and other literature genres to produce teachers who are capable of teaching not only creative writing but also composition, literature, theory and other subjects.

Concerning the characteristics of the students who practiced creative activities, Brookhart (2010) states that they were able to put things together in new ways, construct more novel products, use more unusual imagery to make points, and find in ordinary observed things an area to wonder about. In this respect, writing stories and poetry as stated by (McGovern \& Hogshead, 1990; Cubukcu, 2010; Lazar, 1996; McKay, 1982) are significant stimulations to display creativity as they offer opportunities for students to project their feelings, experiences and emotions in written forms of poems or stories about universal themes and human concerns. Consequently, poems and stories as literary genres have the potential of providing a valuable resource that represents the structures of language authentic texts, which in turn can be considered as a model for students to practice language items in written poetry or story (Brumfit and Carter, 1987). For more details, they added that writing any literature genre is appropriate for students' proficiency and interests that can be used for presentations, language writing practice, and different modes of creative writing because they stimulate students' creativity, language awareness, and inspire them to write their own pieces of literature. 
Following Cubukcu (2010) steps, this study started with an exploration stage where the students teachers`were helped to learn the different genres of literature, their characteristics, and elements. Moreover, students were trained to analyze the elements and concepts of poems, plays and stories, that enabled them to identify the figurative language, use of concepts, express emotions, implement the right grammatical structures and vocabulary, and realize what makes them creative. Then comes the follow up stage in which students were encouraged to convert their grasped knowledge into meaningful creative expressions to compose their poems and stories reflecting their feelings, emotions, experiences and opinions that were edited by the researchers in terms of creativity, usage of language, literature genre elements and characteristics to reach the integration stage of Toondoo Comics.

The flourishing of the digital technology produced a wide range of new methods and techniques in education to enhance the efficiency of teaching and learning of the creative writing skills. Recently, Web 2.0 has turned out to be an important method, used in all education stages. David, (2009) defined Web 2.0 as interactive web applications with three integrated functions: participation through a usercentered design, collaboration with online users, and distribution to facilitate information learning. Thus, Web 2.0 sites are highly interactive and highly engaging. Literature has talked about many university students as being digital residents who are accustomed to experiencing digital technologies and highly participate in social spaces (Wright et al. 2014). Within these shifts, it is important to recognize the difficulties that university students face to benefit from these digital technologies especially when the use of such digital technologies in learning and teaching has long been inconsistent (Selwyn 2014). For Marques (2007), Web 2.0 tools helped professors and students achieve their educative goals. In the same sense, Dooly (2008) revealed that using multimodal resources facilitated students learning where they could actively exchange, debate and negotiate ideas within their groups. On the other hand, Cohn (2012), Brown, (2010), Greenhow, Robelia, \& Hughes, (2009) (Boulos, Maramba, \& Wheeler, 2006; Crook, 2008; Franklin \& Van Harmelen,2007) (Redecker, Ala T Mutka, Bacigalupo, Ferrari, \& Punie,( 2009) found that although many of Web 2.0 technology tools include valuable and sensible categories that offer opportunities for educators and learners to enhance communication, productivity, expressing opinions and facilitating interaction, their various features have never been studied. As a result, Bower (2015) conducted a study using a structured typological analysis technique to Web 2.0 learning technologies reviewed from over two thousand online site links, educational technology texts, online searches and previous Web 2.0 review papers. This led him to identify 212 current Web 2.0 technologies, classified into 37 types of Web 2.0 technologies and arranged in 14 clusters suitable for learning and teaching purposes. One of these clusters is Toondoo tool that includes Comic strips creation which help users to drag and drop characters and backgrounds to join individualized images and text. Comics to Bower (2015) are often used as motivating tools to summarize scenarios or demonstrate processes through the various genres of Comics:_Storyboard That, Toondoo, Make beliefs Comix, Bit Strips, Pixton, and Witty Comics.

One of the Web 2.0 tools that Silva et al. (2012) Anastasiou \& Alves (2004) wood (2008) Olvieira (2014) have proposed as a teaching strategy was Toondoo comics to help students have better creative literature productions. Our main concern in this study is Toondoo Comics which is generally defined as a method of telling tales or relaying tales to the audience by the narrator through multimedia tools. Accordingly, Toondoo Comics to Wiki Books is a great way to assess students' comprehension of story lines, and main ideas as it allows them to easily create cartoons by dragging hundreds of readymade backgrounds, props, text boxes, and characters into the cartoon panel chosen by them. Wiki described how through Toondoo students can change body positions and facial expression, shrink or clone characters, import their own images, and even doodle or create their own characters. Once several cartoons have been created, they can be dropped into a Toon book that students can save, publish it to the world, keep it private, or share it with friends.

Ramos (2006), mentioned that the use of Toondoo Comics was assimilated as a genre to be used by educators as they are representations of the "oral in writing guided by specific rules. Ramos highlights the importance of planning properly when using Toondoo Comics, so that students can achieve better results in learning. For more details, he added that the outline of the balloon indicates the intonation of the voice and the shape of letters indicate feelings or actions, while a larger letter indicates a screaming character and the shaky handwriting resemble a scared character and so on. Accordingly, 
Comics?? OR comics to Guimarães (2001) are artistic expressions that represent movement through motionless images and to Eisner (2010) they are a successful teaching strategy for undergraduate students to write creatively using images and words to write a story, a poem or dramatize an idea. Consequently, many authors, Guimarães (2001), Glaeser, Pierson, and Fritschmann (2003), Ramos (2006), Langer (2009), and Rebolho, Casarotto, and João (2009) agreed that Toondoo Comics can be used for several education purposes: producing knowledge, enhancing creative writing skills, developing foreign language skills, motivating students to participate and making classes more attractive.

Referring to Kaya (2013), Creative writing is an expression of all information, gained from observing the outer world, in a manner that is different from other people. Similar to many authors, kaya identified creative writing using Comics as the preparation and presentation of events in a creative writing mode similar to an exhibition of creative thoughts expressed in forms of stories, poems, folktales, cartoons. Similarly, to Kucuk (2007) Creative writing means going beyond the ordinary and away from normal values, displaying thoughts that are different from others by expressing the imagination, catching originality, writing fluently, taking pleasure from writing and going beyond the standards. Moreover, Kaya (2013) research showed that genres as music, cartoons, poems and stories contributed to the development of students' creative writing skills. According to the studies conducted by Jakes (2006), Karakoyun (2014), Demirer (2013), Hung et al. (2012), and Yang and Wu (2012), findings showed that story writing using Comics reflects students' abilities to write creatively and developed their writing abilities, problem solving skills, critical thinking skills, academic achievement, learning strategies as well as their motivation to learn. Summing up the benefits of writing literature productions using Toondoo Comics, Arslan (2013) states that it is usually the result of a meaningful synthesis of subject area knowledge, pedagogic knowledge and technological knowledge. He added that this educational method helps students achieve their learning goals through expressing their feelings, emotions, opinions using Toondoo Comics to present their stories or poems and display their personal experiences and style.

Through all what was mentioned under this title, there was a call for teachers and students to use Toondoo Comics for learning and teaching different subjects in different levels of education. As a result, Caruso \& Freitas, (2009) a high school physics teachers who introduced the ideas of Einstein in class using Toondoo Comics made by students, could realize that this strategy was beneficial to teach and motivate students as it created a perfect interactive class environment through the encoding and decoding processes students experienced in creating and interpreting their Comics which facilitated their learning, and helped teachers attract students' attention and motivate them to interact and participate. Similarly, the studies of Rossetto \& Chiera-Macchia, (2011) reported their experience of using Toondoo Comics in teaching the Italian language where students were asked to build a story as a group using Toondoo Comics, submit it, then deliver a written reflection about their experience. Through students written reflections the researchers noticed that this tool helped the development of students' memory, analysis, and reasoning. In the same sense, Jensen et al. (2007) as cited in Ram, Rev. Adm. (2015) find that the use of drawings was a successful method that helped students be motivated to express their emotions, develop their creative writing and decrease their anxiety. Thus, to Jensen et al. (2007), drawings can be used as a research method to capture emotional and aesthetic aspects of the experience and can also be a way to acquire knowledge and generate interpretations of research participants. Accordingly, the study results of Kiliçkaya and Krajka (2012) who examined students' attitudes and reactions toward creating Comics using Toondoo, indicate that out of 25 students, participated in the process, 24 claimed that they liked the activity in which they spent five weeks creating Comics in class, then sent the produced material to the teacher, who reviewed and commented on it. The authors concluded that among the contributions of using Toondoo Comics in teaching were the development of students' autonomy, freedom of expressing, and creativity, in addition to the fact that it is a student-centered education strategy. Similarly, Wurdinger and Carlson (2010) highlighted that active learning helps students to feel free to express their ideas, creates suitable learning environment where students can explore ideas and challenge the ideas of others as well as think.

While many studies explored the effect of technology in education and found that it is a method that can foster students' creative writing skills, Foley (2013) contradicted the results of many mentioned 
studies that considered Toondoo Comics an effective method to enhance students creative writing and motivation when he stated that Toondoo Comics cannot be used as an effective method to determine students' perception of writing, enhance students' writing skills, create an author identity in students, improve academic writing and involve students in the writing process.

To sum up, Xu et al. (2011), Kulla-Abbott (2006), Green (2011), and Kaya (2013) consider Toondoo Comics one of the suitable methods through which students can express themselves creatively, and feel motivated to present their literature productions, enhance their creative thinking skills and improve their creative writing skills. Thus, in education, creating comics by the students is considered as one of the important active learning strategies. Since most of the studies agree that Toondoo Comics stimulate the participation of students, contributed to the development of their thinking abilities and creativity, made the learning process more interesting and motivating, this study, used Toondoo Comics as a way to examine students' representation of the knowledge acquired through the covered courses, as well as its effect on students' creativity, motivation and attitudes toward integrating this tool.

Therefore, and through all what was mentioned so far, it was encouraging to examine the impact of Toondoo Comics integrated in the English education courses on the Lebanese university student teachers' motivation, perceptions and creativity in writing poems and stories.

\section{Methodology}

\section{Research Design}

Following the Inquiry Mode grounded in this quantitative and qualitative study (Strauss \& Corbin, 1998), the focus is on the content of student responses to the pre $\backslash$ post questionnaires. In order to accomplish a view of the participants' experience, this research employed a mixed method design where the qualitative study is a thematic coding of the observation and discussions, while the quantitative one is related to pre post questionnaire results. Thus, it is an experimental quantitative qualitative study, with no control group that describes the differences occurred in students' pre $\backslash$ post opinions, skills and attitudes affected by integrating technology in education. The collected data were analyzed and synthesized as bases for findings and conclusions, upon which implications and recommendations were formulated.

\section{Participants}

The respondents of this study were 14 second and third year undergraduate student teachers enrolled in English Education Creative Writing and Children Literature courses, offered at the Lebanese university, faculty of pedagogy, branch 2, during the academic year 2017-2018. The participants came from diverse cities and villages in Lebanon and majored in different education fields; English language teaching, French language teaching, Arabic language teaching, science teaching, math teaching and art teaching. As a start, the participants were introduced to the various literature genres, and the concepts of critical reading, critical thinking, and creative writing as well as the techniques of expressing their feelings using consciousness, empathy, and the learned figurative language knowledge. The next step was related to one of the course goals in which student teachers were engaged in a series of creative assignments related to writing, reading, presenting, reflecting, analyzing, synthesizing, reviewing and editing. Thus, a set of creative writing assignments were designed by the researchers where students ended up writing their poems and stories that required the researchers' to review, reflect, comment and edit as well as a special control for the process of integrating Toondoo comics in their literature productions.

\section{Procedure}

Under the supervision and guidance of the researchers, the participant had to cover the teaching routine involved in the objectives and syllabi of the Creative Writing and Children Literature courses assigned by the department of English education at the Lebanese university faculty of pedagogy, followed by a training workshop to teach the participants the techniques of integrating Toondoo Comics in their assignments. In order to address the issue of engagement, boost student confidence as creative writers, and develop their writing abilities, a series of creative activities were introduced in the two courses during the fall and spring semesters of 2017-2018. The assigned activities were grounded to the two course descriptions and syllabi dealing with the issues related to theories, reading, analyzing, criticizing and evaluating various genres from the English literature. Moreover, 
students in both courses were evaluated for their critical reading and analysis of different types of stories, poems and plays as well as for writing creative poems and stories using Toondoo Comics. According, to the concept of integrating Toondoo Comics, the students were given the clues to post their Toondoo outputs that were subjected to online collaboration, research, documentation explanation, discussion, analysis, presentation and evaluation. In other words, online construction process took place between students and the researchers for 7 weeks in each course.

The idea for this study dates back to the end of the academic year 2016 - 2017, when the researchers of this article, who teach undergraduate students technology and English education courses offered at the Lebanese university faculty of education, realized that the majority of student-teachers were struggling with the way the courses' assignments were handled that led them to show low levels of engagement with class activities and assignments. The main causes behind student teachers`struggles were attributed to the hard efforts they have devoted to address the requirements of the course with their limited English skills and their being not English majored in some cases. Above all, the final evaluation stage showed that student teachers were not interested in the way their literary productions were handled, wasted and ignored after being graded which was a main cause for their demotivation and regret taking the course. Referring to our responsibility toward students, we had to look for solutions and that was the starting point. Thus, getting the approval of the faculty of Pedagogy dean to conduct this study was our first step.

The current study presents the results of students' motivation, perceptions and creative writing abilities before and after implementing Toondoo Comics in a series of creative writing activities. Thus, data collection focused on the content of students' creative writing productions using Toondoo and their attitudes towards implementing Toondoo in both Creative Writing and Children Literature. The study ended up with pedagogical implications of the study and suggestions for further research.

However, for the researchers it is likely best to consider a slightly different production process. That is, the study starts with a pre questionnaire to evaluate students' motivation, perceptions toward technology integration in the teaching $\backslash$ learning process and toward creative writing. Then, student teachers were given definitions, theories and discussions for each genre of English literature. Reading samples of each English literature genre, discussing and analyzing its elements and what makes it a creative pieces of literature were part of the procedures conducted in class. The practical part included students' written analysis for different genres of literature discussed in class, followed by further development and editing. Finally, students had to express all what they learned from class explanation, discussions, analysis and so on in their own written poems and stories reflecting their learning, emotions, feelings and life experiences. Presentations of students' literary productions in class offered classmates and researchers the opportunity to reflect and give their feedback which helped developing students' written poems and stories. The integration of Toondoo Comics took place directly after students' literary productions of poems and stories were reviewed and edited. By week 5 Dr charbel Seaman the IT assistant professor, who used to attend Monday sessions, started with a workshop about introducing Toondoo Comics and the steps to integrate this technique in students' literary productions. The workshop ended with examples and illustrations as well as with some practical activities about how to choose the right pictures, colors, characters, background and so on that suit different types of sceneries or events in participants` stories or poems. Consequently, the integration of Toondoo in students' poems and stories was completed under the supervision of the researchers through attending classes to observe student teachers` reactions attitudes and motivation, mails, and messages in which students' work was controlled and edited. Towards the end of each of semesters 3 and 4, students completed a post questionnaire about their attitudes and perceptions regarding the two courses and the integration of Toondoo in these courses. In this sense it is worth to mention that the task of writing creative stories and poems could not have been perfect without the help of this Toondoo Comics and the computer resources.

In conclusion, it is important to mention that students were encouraged to write their weekly assignments that helped the researchers to check their writing skills and creativity improvement, for thirteen weeks. Through readings and editing students' productions it was noticed that their writings focused on their feelings, emotions, reactions and attitudes toward their real life experiences. 


\section{Instrument}

To achieve our study purpose it was impossible to start the intervention of Toondoo before achieving the objectives of the two courses so that students will be able to identify the different genres of literature productions, their characteristics and elements that make them creative pieces of literature. Thus, the start point depended on various types of references related to Children Literature and Creative Writing course objectives; books, stories, poems, plays, that were chosen in accordance with the courses objectives from the modern and old English literature. The objectives of these courses can be summarized by students' ability to identify the different genres in literature and to write creatively using sophisticated language and advanced writing strategies as well as using advanced reading strategies when reading sophisticated texts so that they become creative writers. To achieve the mentioned objectives, the participants_were required to analyze, discuss, present, reflect and write different genres of literature. As for the activities conducted in teaching these courses we can say that reading, analyzing, synthesizing and discussing poems, plays and stories selected by the researcher, teaching these courses, from the English literature were basics in teaching these courses. Furthermore, these courses offered an opportunity for students to express their ideas, opinions, feelings and emotions in written creative forms of poetry and narration. Regarding Reading, revising, editing and discussing students' written short stories and poems that were guided by the teacher and shared by the students could be considered as common strategies conducted in the two classes. In short, the two course requirements were students' ability to write creative stories and creative poems.

To examine the effect of integrating Toondoo on students creative writing and motivation toward the taught courses, and to identify the differences occurred in students before and after the intervention of Toondoo Comics, the researchers had to prepare a pre post questionnaires derived from literature, consisted of ten and eight questions consecutively. The pre questionnaires helped determining students' evaluation of their writing skills, their knowledge, opinions and attitudes toward integrating technology in the teaching \learning process as well as their readiness to be authors of stories and poems before the intervention of Toondoo Comics. At the end of the semester students had to answer eight open ended post questionnaire after the intervention of Toondoo Comics, so that we could reveal students' attitudes and opinions about integrating Toondoo comics in the covered courses. Moreover, the post questionnaire aimed to diagnose the level of improvement occurred in students' writing skills as a result of taking these courses (creative writing and Children Literature) and the extent to which motivation Toondoo Comics have created in them to come up with their literary productions.

Toondoo was a main tool that helped creating active learning classes where students got a detailed workshop to learn how to integrate it in their productions and transfer their pieces of literature into real stories and poems that could be published. Wikibooks described Toondoo as an easy tool to use; with only few mouse clicks and drag and drops students can create their own comic strips and edit. For more details, we can say that this tool enables students to choose from a vast variety of characters, props and backgrounds categorized into specific galleries or create their own characters by using the Trait R (a tool that allows creators to give a particular quality to the character). To Wiki Books Toondoo is an an exciting and amusing tool that makes class assignments interactive which inspire students' imagination and creativity. Moreover, it makes language-learning fun as it affords the availability of creating characters and choosing pictures that enables pictures to speak louder than words and motivate learners to use what they have learned in creating their own stories and poems. Consequently, Toondoo Comics can be used as a test to evaluate students learning of new concepts and skills.

Regarding all what was happening in the two courses, the researchers were applying the technique of observation during class activities, discussions and presentations to collect more data through a record of all occurred changes in students' creative writing, reactions, motivation and attitudes.

\section{RESULTS AND ANALYSIS}

The purpose of the study was to determine whether Toondoo Comics would lead to the development of undergraduate students' creativity in writing stories and poems and their motivation as well as their attitudes toward the Creative Writing and children literature courses taught at the Lebanese university, faculty of pedagogy, branch two. The number who actually participated in the study was statistically a significant number as it included all students taking the mentioned courses, that in turn would allow 
The Impact of Toondoo Comics on Undergraduate Students Taking Creative Writing and Children Literature Courses at the Lebanese University Faculty of Pedagogy

generalized comments to be addressed. Three types of measures were used to collect data: students' pre and post questionnaires and the researchers' observation notes. In order to investigate students' attitudes and motivation toward integrating Toondoo Comics in the education courses taught at the faculty of Pedagogy, and its effects on students' creative writing after 13 weeks_of intervention, as well as to answer the study questions, simple excel statistical operations were used for data analysis.

\section{Descriptive Statistics}

\section{Pre Questionnaire Results}

Questions 1 to 8

\begin{tabular}{|c|c|c|c|}
\hline \multirow[t]{2}{*}{ Questions } & \multicolumn{3}{|c|}{ Answers } \\
\hline & Weak & Average & Good \\
\hline 1- How can you evaluate your writing skills? & 3 & 7 & 4 \\
\hline 2- What do you think of writing a story and a poem before graduation? & 2 & 4 & 8 \\
\hline 3- What is your level of readiness to write different literature genres? & 1 & 10 & 3 \\
\hline $\begin{array}{l}\text { W- What do you think of using an internet tool to publish your written } \\
\text { literature productions? }\end{array}$ & 1 & 4 & 9 \\
\hline 5- How much knowledge do you have about Toondoo tool? & 8 & 6 & 0 \\
\hline $\begin{array}{l}\text { 6- How would you evaluate students who publish stories and poems at } \\
\text { an early age? }\end{array}$ & 0 & 2 & 12 \\
\hline 7- $\quad$ How would you feel when your work is published? & 0 & 2 & 12 \\
\hline How would you evaluate your attitude about writing assignments? & 1 & 8 & 5 \\
\hline
\end{tabular}

The following charts Summarize the above table results:

\section{Question 1}

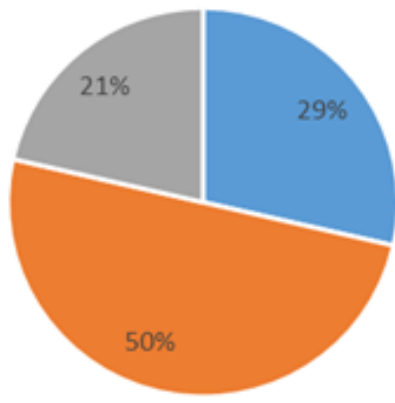

" Good = Average = Weak

\section{Question 4}

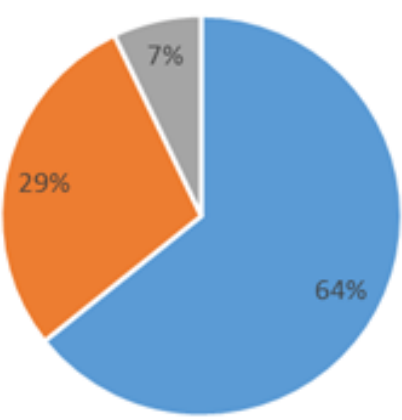

" Good = Average = Weak
Question 2

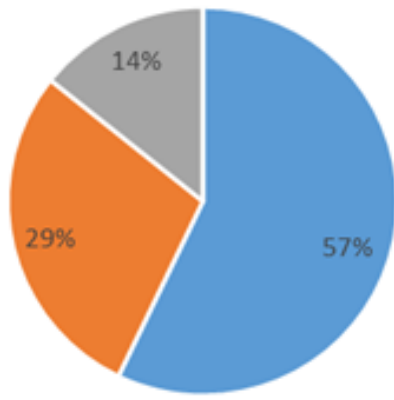

m Good = Average = Weak

Question 5

$0 \%$

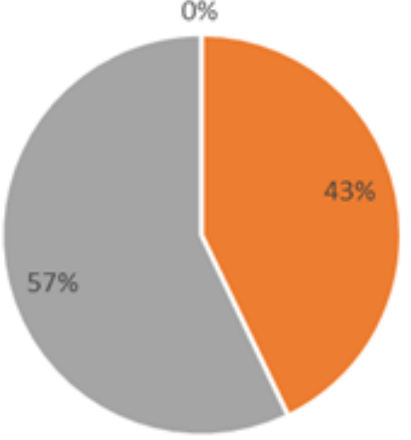

m Good = Average $=$ Weak

\section{Question 3}

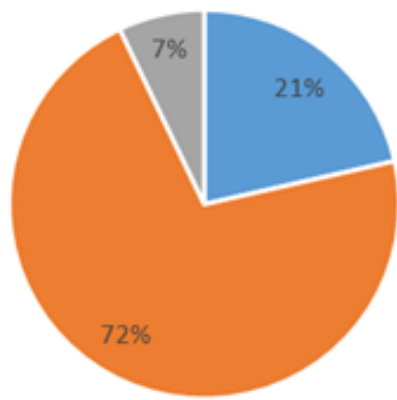

mood = Average = Weak

\section{Question 6}

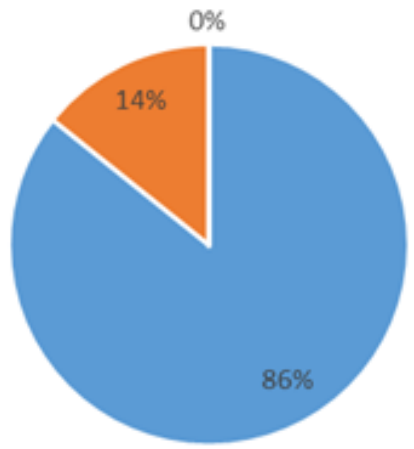

" Good = Average = Weak 


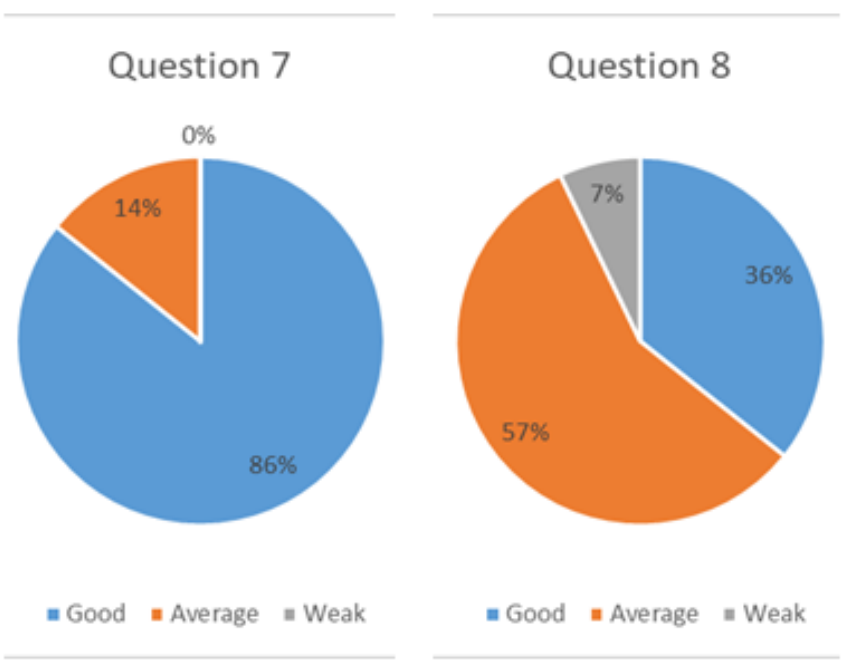

The above table and charts present a part of the pre questionnaire students' answers where their answers to Q1 shows that most students' writing abilities ranged between weak and average before covering the courses content and integrating Toondoo Comics. While Q 2 students' answers reveal that most students liked the idea of writing stories and poems, Q3 answers indicate that students were not completely ready to write any literature genre. Moreover, the results of Q4 and Q5 also reveal that while most students liked the idea of using the internet tool to publish their written productions, 8 students out of 14 did not have any idea about Toondoo Comics and the other 6 students had average knowledge. Although the majority of students presented average attitudes toward the writing assignments (Q8), their answers to Q6 and Q7 indicate that almost all students considered the idea of being authors as a good idea and that they feel proud of themselves when they become authors.

To continue analysing students' answers for the pre questionnaire second part questions, consisted of two open ended questions (Q9 and Q10) and concerned with students' reasons behind their lack of motivation to write literature genres and their opinions about integrating technology in English education writing courses. Analysing students' answers to

Question 9: Why do you think many students are not motivated to write stories and poems? we noticed the following:

- Many students claimed that they are very good at writing stories but they lack the motivation to write, lack of time and inspiration as well as facing they have difficulties in picturing their ideas and finding the right images or pictures to associate them with their work

- Student teachers do not like writing in general, so they lack encouragement to write.

- they do not know the strategies and techniques to write creative stories and poems, or not well trained and formed to do it properly

- They find the topics boring and repetitive.

- They are not passionate readers.

- They underestimate their abilities.

- They are not used to write such forms of literature.

- Schools do not give importance to creative writing

- XX (fragment) Because of their laziness

- They have never been encouraged and motivated before or given the opportunity and enough time to show their writing competencies.

Moreover, students' answers to question 10 (What is your opinion about integrating technology in English education writing courses?) can be presented as the following:

- I like the idea very much, It will be more interesting and captivating to integrate technology tools in the teaching $\backslash$ learning process that enhance learning of the English language.

- I am with technology integration. 
- It will be very good because technology nowadays is used in schools

- I think nowadays technology is around everyone, especially the kids, so it is interesting for the students to use it in EFL writing courses.

- It motivates students to be engaged and participate.

- It is necessary for the course, as it engages and immerses students in the language through reading which is unrecognised these days.

- The course will be more motivating and will enhance the interaction between students themselves and students with teachers.

- I think that it is a good idea to help student writers make better stories that motivate readers to read them till the end.

- That would be a great idea.

- It decreases our imaginary and critical skills

- It would be a great idea because students will be more connected to the course.

- It will grab the students' attention more.

- I believe it is important to integrate it because it gives the writing course life and encourages students to write.

- It pushes students to write more, and experience being authors at an early age.

The previous mentioned students' opinions revealed that $85 \%$ of the students were with the idea of integrating technology into the English education writing courses. The majority of students have claimed that through this technique, the university courses could be more interesting and motivating where students will be encouraged to read and write different genres of literature. Moreover, their answers showed that students were aware of the benefits of integrating technology in their courses as they mentioned that it helps grabbing students' attention, creating an interactive environment in learning and involving them in writing.

\section{Post Questionnaire}

The answers to the post questionnaire are detailed here after:

1- Which of the course followed strategies helped you to write your piece of literature? Why? (Technology, practicing, analyzing literature texts etc.)

- The Children literature course taught me all strategies necessary to write my pieces of literature.

- Practicing. As they say: practice makes it perfect. The more I practice and change and add to my work the more authentic and creative it gets

- The Creative writing course helped me write my story, and inserting technology pushed me forward.

- Text analysis, since it helped improve and enhance my critical thinking.

- Many strategies such as technology and the course itself with the analysis discussions, helped me to be more creative in writing my story and poem.

- Technology and analyzing literature texts, helped me to have an idea about writing a story and a poem as well taught me what and how to choose pictures, characters and background.

- All strategies helped me in writing my pieces of literature yet the most effective one was analyzing literature genres, without this analysis, we couldn't have been able to write good pieces. using this strategy in class, allowed us to know what every genre of literature should include to be creative.

- Through Children literature course we learned the different literature genres and their characteristics that helped us enrich our English language figurative language, vocabulary and grammar. 
- Analyzing literature helped me to write the story and the poem. It offered the necessary knowledge to know how to write a good story and a good poem in addition to realizing that literature is connected with all subjects.

- Technology, literature texts helped me to express my own ideas in a creative way.

- Practicing analyzing literature genres of poems and stories in class helped us to write our own literature productions.

- Analyzing literature texts was the core in writing my creative pieces. I concluded that to write creatively means to care about deeper meaning more than the sum or words,

- The technology and analyzing literature texts taught me to write stories and poems and how to convert it into a comic story based on the needs of my future students.

Analyzing students' answers for Q1, it was obvious that most students agreed that the techniques and strategies followed in teaching the two courses were beneficial to enhance students' creative writing, language, grammar etcetera. Mainly the followed analysis strategy, helped students identify the elements of literature genres and their characteristics in addition to writing similar forms using the right language, techniques, expressions, structure, vocabulary and organization necessary for writing. Furthermore, the technology text was a favorable strategy to all students as they expressed that it helped them learn a new teachingllearning strategy that facilitated converting their written words into expressive pictures. Similarly, the practice strategy also affected students' learning to write creatively as it enhanced their fluency and expressing their ideas. Finally, there answers presented positive results towards strategies and the techniques followed in teaching and learning the English education university courses.

2- What do you think of integrating Toondoo tool in English education courses learning /teaching processes? Would you use it as a tool in your future teaching career? Explain why and how?

- Toondoo is so useful to use in teaching my future students for it helps them understand assigned language texts and motivates them to participate and focus.

- Boosts and pushes the students' creativity. It can be integrated as a course practice or activity in class; assigning students into groups or solo and ask them to create a nice short story using Toondoo.

- ??? Ease the learning process for the students

- Toondoo will encourage and motivate students to participate.

- Is very helpful in creating nice stories and images for students that makes teaching more interesting for the students to have more fun.

- It is a nice tool to work with and create the story images.

- It is a very effective tool that I am planning to have it as a final project, because it encourages student to work more. It can be used in all education levels.

- It can enhance student's creativity. Teachers can write a story about a specific theme and adapt it into a real story or into comics. students can also use the characters they want

- Students can be invited to write their own stories, and then teachers will explain how to do their own design. It helps them to choose the right characters or picture suitable for the written sentences.

- It is something very creative to use and consists of suitable techniques that attract children's attention.

- Children love to see visually the characters and the setting of the story so Toondoo is perfect for this.

- Toondoo can be integrated into all topics and subjects to engage students in a fun interactive session.

- Toondoo helps students be motivated and easily understand the lesson. 
The above students' answers indicate that all the students agreed that integrating Toondoo tool in Education English courses learning/teaching is a great idea and that they would definitely use it in their future teaching practices. For more details, almost all students are planning to use Toondoo in their future career as a tool for teaching as it helps facilitating the students learning, makes it fun and motivating. Moreover, participants' answers showed that their experience with Toondoo was successful, while another student claimed that she will take Toondoo as a topic for her final project. All in all, almost all student teachers agreed that it helped them be more creative.

\section{3- Do you think the course has developed your English education courses' writing skills? In} what areas? And how could you know this?

- Yes it helped me and developed my writing skills. Because I learned from my mistakes and I corrected them according to the doctor`s comments.

- Yes, it did help a bit. It helped visualizing the story and made it more alive.

- Yes it showed me how to do it properly

- Yes, in creativity since I am able to analyze and think clearly, when I want to write

- This course developed my EFL writing skills. It helped me to be creative and to connect my ideas. I realized this, while I was writing I had to pay attention to the order of my ideas.

- It did, especially in language, choice of ideas, mechanics and vocabulary, we learnt this through the teachers`comment and the vocabulary we used in discussions.

- The course has developed my EFL writing skills; first, it developed my creativity as well as my language. I knew this when I wrote my final story and poem that will be published

- Yes, it did because I was able to write a story with a good English level. It helped me organize better my ideas, the coherence of the text, choice of expressions (idioms), appropriate vocabulary.

- Of course, the course has developed my EFL writing skills. Sentence structure, vocabulary, flow of events, coherency, flow of incidence, organization. I could know this from the teacher`s feedback on my final literary productions.

- Yes, it enhanced my language, my vocabulary knowledge and different techniques. I was able to write an organized story, and my grades improved

- I expected to develop and improve my writing skills more; the course helped me analyze the creativity in poems and stories (the figurative language and the imaginary).

- The course helped me notice the creative areas in the analyzed texts and poems that helped me analyze and write similar pieces. At the end of the semester I was able to notice the smallest detail in poems and literature.

- Yes, the course has developed my EFL writing skills; I didn't know that I have the ability to write a story or a poem, but I need to practice more for better stories.

Thus results demonstrated that $100 \%$ of the students agreed that the course have developed their EFL writing skills in several areas such as: Language, choice of ideas, the flow of events and incidence, mechanics, the coherence of the text, choice of expressions (idioms), appropriate vocabulary, sentence structure, creativity, analyzing and critical thinking in reading and writing. Finally, we can say that to teach your students how to write properly, visualizing a story and making it more alive, taking creative writing courses and using Toondoo comics would be of a great help.

\section{4- What did you like most about the course?}

- Using creativity and analyzing stories and thinking outside the box were my favorite.

- Analyzing different stories and discussing their different writing techniques and writing our own stories and poems were very interesting strategies in the taught courses.

- We had the chance to write our own stories and poems, and we learned how to improve our creative writing skills. 
- Writing our own stories and using the free Toondoo tool where texts are turned into images were my favorite in taking this creative course.

- Its content is something that we can implement in our future career

- How to use an application and planning a good lesson that will motivate the students and make them active and attracted to the lesson.

Answering question four revealed that most students liked integrating technology in the creative courses. Results also showed that students were able to realize their writing skills development when all students claimed that they were able to write stories and convert them into comics through using toondoo.

\section{5-Was Toondoo helpful to elaborate your written stories and poems? What difficulties have you faced when you converted your literature product into Toondoo comics?}

Answering question 5 revealed that although students were interested in the process of converting their written and edited literature productions, they faced many difficulties

- It is helpful. I had a problem to translate it and how to find my characters in the beginning but later it turned to be fun.

- The characters and other items in the program were tricky to find or create. Some of the characters have limited facial and poster features that were hard to compromise it to the story

- Have never used it before

- Yes, and i faced no difficulties.

- Toondoo was helpful because i was able to express the ideas in my story. The difficulty was with finding suitable characters for the story and poem.

- Yes, it was helpful because the pictures were harmonious with the story, but I found some difficulties in fitting the text on it at the first.

- Toondoo is helpful in elaborating our written stories and poems yet I had some difficulties at the beginning in finding appropriate characters and scenes.

- Yes, but the characters did not exactly match what I wanted.

- Toondoo is a helpful tool to write stories. But it needs some time to find the characters and background that you are looking for

- Yes, it was very helpful but it took time to find all the emotions and posters I wanted.

- It helped me elaborate my written stories because the ideas with the characters and the images the work was elaborated.

- In the poem aspect I did not find it helpful, however, for the stories it was definitely useful and interesting.

- Yes, it was helpful, although I had some difficulties applying the story in Toondoo because it was a new tool to use and needed more time and practice. However, it became a very interesting application that made my story more attractive and animated.

Through the above mentioned answers to question five, it was clear that almost all participants faced difficulties using Toondoo at the beginning which turned to be fun at the end. On only participant did not find this technique suitable for poems while the others showed interest in using it.

6- Which of the following writing skills (Structure, creativity, organization, language, vocabulary, mechanics, expressions, unity, coherence, fluency, choice of ideas and so on) have the covered course and Toondoo tool developed in your writing abilities? Explain.

- Works on creativity, and make the stories more successful and original, as creativity is essential in writing stories and poems

- Helps you to know how to increase the writing skills, how to add your ideas and organize them 
- Makes the story more attractive and interesting for kids to draw their attention

- Assists in an easy way to choose the characters, backgrounds, settings, and so on.

Almost all students' writing skills were developed at the end of the semester and after covering the courses and integrating the Toondoo tool, where most of the objectives proved to be achieved through students' creativity, organization, structure, figurative language, expressions, choice of ideas, vocabulary, unity, mechanics and fluency used in writing their pieces of literature and expressed in their answers to Q6.

Concerning Toondoo tool, students' answers show that most of them were affected by the creativity and organization skills necessary for the process of converting their written productions into Toondoo comics.

\section{7- Are you planning to continue publishing your written stories and poems using Toondoo?}

- I will do it of course because I like it so much"

- I do not think so.

- No I won’t.

- Yes I will use continue to write stories and publish them.

- Yes I will use Toondoo and continue writing poems and stories.

- I will continue publishing my written stories using Toondoo.

- Yes I hope so and I will definitely keep writing stories and use Toondoo

- I hope can continue and publish my own stories.

- Yes, definitely I will keep on writing my stories.

- Yes I wish, I liked working on Toondoo but I will continue writing stories and poems.

- I will use it in the future to write stories for my students.

- With no doubt, it has been very interesting so I will continue using toondoo in my stories and poems.

- I will continue to write stories and poems, and will use Toondoo too.

Answering Q7 reflected students' interest to continue writing stories and poems after succeeding the course. 10 out of 13 students claimed that they are planning to continue writing literature genres using Toondoo and publishing them, because they liked it, as it is user friendly and a very interesting application especially for students. Whereas, the rest varied between no and and wish to continue which means one is not quite sure she will continue to write literature genres using Toondoo due to lack of time availability perhaps, while the last 2 did not like it as they revealed they will not continue using it.

\section{8- How do you feel when you are a young author publishing your written pieces of literature?}

- It is something very special and it is something new for me.

- It feels great and exciting yet I feel a bit anxious about other people's opinion.

- Excited

- I feel like an influencer to youngsters

- It excites me that I am able to accomplish this skill and be able to show and interest kids with my writing.

- It is a nice new experience

- I felt proud and excited

- I feel proud of myself 
- I feel proud of myself and I like to encourage all my students In the future to write their own stories

- Proud, wish for better experiences

- Proud of myself, I felt as if I am an author. I liked the idea of writing something so people can read it

- My dream is to be able to write stories/journals, so this course offered a new beginning and I am grateful

- I am proud of myself because I did not know I could write a story or a poem for children.

Almost all students (13) felt proud, excited of themselves being young authors. It was a new experience especially when they wrote stories and poems and some of them would try to encourage and influence their students to create their own stories and use Toondoo.

\section{Observation}

Evidences of observation, discussions, follow up, conversation, guidance, and corrections explain the results more. Analyzing the researchers' observation notes concerning students` reactions during the intervention of Toondoo Comics in teaching children literature and creative writing courses to investigate its impact on students' motivation and creative writing was not an easy task. Many students were motivated to raise various types of questions concerning certain Toondoo techniques so that their literature productions' characters, background, colors as well as page design were conducted during the discussion sessions. During one of the discussion sessions, the researchers asked the students whether they were enjoying writing their poems and stories using Toondoo comics. The majority of the students expressed that they were enjoying it; for example one student teacher said, "I like Toondoo comics most because I can choose the characters I imagined while writing, and express my feelings in pictures. Another student said, "It is interesting and fun to integrate technology in what we have learned, it helped me using figurative language to express in an exaggerated way my feeling and ideas in pictures". In other way it reflected what student teachers really_wanted to show in their poems and stories. Many students expressed their enthusiasm to write creatively through asking for expressions and vocabulary following the researchers to read and comment on their work, aiming to produce the best pieces. Students' motivation to work on their assignments at home in the university cafeteria were more than enough to realize students' joy towards the courses and Toondoo. In the same sense students' calls messages mails running for the opportunity to ask a question whenever they meet the researchers at any place at the university; parking, office, teachers' lounge and even in the pathway while shifting classes. Their nonstop questions were awesome signs that showed students' interest, motivation and seriousness about the requirements of these taught courses. Not to forget students' request to postpone the submission deadlines so that they could work more for better productions.

More questions were asked related to the strategies students' followed to overcome the difficulties they faced while writing their poems and stories. One motivated student mentioned that she used a dictionary to look for needed vocabulary, another searched in the internet to read more poems, stories and to look for creative expressions so she could improve her literature productions.

Concerning the researchers editing and feedback, most students found that the correction of their mistakes and the comments as well as the feedback were beneficial and encouraging. What was obvious through observation was students ${ }^{\text {ee }}$ positive reactions to interact and express their points of view. Furthermore, the students enjoyed the discussion sessions where they proved to be good listeners focused on the content of the courses in class and showed interest in commenting and claiming their feedback. Students were very proud of their written productions in a way that all wanted to present their stories and poems at the same time which obliged the researchers to set a schedule for the two classes so that every student could have a chance to present during the intervention. In general, students interacted enthusiastically, and looked eager to know that they were improving their writing.

Concerning students' development the researchers could notice that the first three weeks were difficult for students to adapt with the requirements of the courses. While time was passing students in 
the two classes were able to be motivated and involved due to the interesting creative poems and stories they read analyzed and synthesized.

Comparing students' written productions, the researchers realized that they were developed in structuring their creative sentences, organizing their ideas, using figurative language, and expanding their information following the taught elements and characteristics of literature genres, but that was not enough as long as students; especially non English major students, still have some language, mistakes subject verb agreement faults and more concerning grammar, mechanics and structure which were corrected by and edited by both researchers. Finally, both researchers were satisfied with the study results in which students were motivated, proud of their work and succeeded in converting their creative written stories and poems into comic books using Toondoo. Consequently, as researcher we agreed that if students continue to write regularly for one more year they will become good writers. Similar to mayers (2009) and Brookhart (2010) this study pre/post questionnaire results and the observation showed that Toondoo comics technique have affected students' attitudes and creative writing skills positively which means that the study questions were answered.

\section{DISCUSSION}

The main purpose of the present study is to determine whether Toondoo Comics would lead to the development of university students' creative writing skills and their attitude toward the English education courses taught at the Lebanese university faculty of Pedagogy. Thus, this study aims to explore the importance of teaching the creative writing courses and the differences occurred between students' opinions and attitudes towards integrating technology in these courses' learninglteaching processes, before and after implementing Toondoo comics in Children Literature and Creative Writing courses.

The technique conducted in this study has been found to be effective in arousing students' interest in writing creative literature genres and converting them into comics using Toondoo, which reflected students' developed creative writing skills, enhanced language abilities, and motivation to write creative poems and stories and convert them into comics. The findings of the present study provide further confirmation for the results of previous studies concerning the effects of teaching Creative Writing courses to enhance students' creative writing and language skills that enable them to express their feelings, thoughts and knowledge in an interesting way. Answering the first three study questions, our findings show apparently similar results to the studies by Sivasubramaniam (2009), James (2009), Larkin (2009), Maley (2012), MoNE (2011) in terms of the importance of teaching creative writing courses in developing students' writing skills and creativity. Comparing the results of pre post questionnaires and the researchers' observations and discussions, it was obvious that through teaching creative writing courses, conducting creative activities, and implementing creative strategies, the_participants were able to be authors of creative stories and poem. Moreover, comparing our students' average writing skills' level before starting the creative writing courses with the post questionnaire results, it was clear that almost all participants' writing strategies, writing abilities and creative writing skills were developed and turned to be good after covering the two courses. Such a significant improvement implies that our students were able to write creatively when the right teaching courses and the right techniques were implemented. Nonetheless, the results of the conducted post questionnaire, after the students' practice of creative writing activities indicated a marked difference in almost all students' knowledge, creative writing abilities and outcomes.

The differences occurred in our participants' post questionnaire were similar to Stillar (2013) in terms of students' motivation and engagement in creative writing activities that helped them experience higher levels of enthusiasm and motivation reflected in their enhanced writing abilities and their free imagination employment to come up with creative poems and stories. Consistent with Cook's (2000) results, the creative writing courses did not only foster our students to discover the language only but to discover themselves too. Furthermore, through teaching creative courses, and through our students answers to the post questionnaire were able to know that their creative writing was fed from the creative strategies ( reading, analysing, synthesizing, practicing, reflecting...) and the focus on the aesthetic reading skills implemented in teaching \learning the creative courses ( creative writing and children literature) provided them with a better understanding of the textual construction that contributed to expressing their feelings, and awareness in creative writings. Likewise, and similar to 
many authors' results like Lee (2012) and Demir (2013) the creative activities implemented in our creative courses ended up with many students' creative literature productions that reflected greater levels of creative thinking derived from the acquired information merged with their prior knowledge to come up with new ideas engaged in their assignments and posted creative poems and stories. When students' responses to the post questionnaire were analyzed, the results were apparently similar to Barjesteh, Vaseghi \& Gholami (2011), in which the participants proved to be aware of their improvement in most creative language skills and writing strategies.

The answers to questions four and five concerned with studying the effects of integrating Toondoo comics in English education courses on students' creative writing and motivation were clarified through comparing the prelpost questionnaire results that revealed similarities with those of Jakes (2006), Karakoyun (2014), Demirer (2013), Hung et al. (2012), Foley (2013), and Yang and Wu (2012) where most of our participants could realize that using Comics in creative writing motivated them to develop their writing abilities, problem solving skills, critical thinking skills, academic achievement, writing strategies as well as their overall learning. Apparently similar to the findings of Barbot et al (2012), Brookhart (2010), and Cubukcu (2010), the majority of the participants' answers showed interest and encouragement in the covered courses and the integration of Toondoo comics that helped them to write creatively and transfer their imagination into written expressions. Summing up our results of integrating Toondoo Comics in creative writing and children literature courses presented by the students' answers to the post questionnaire showed that this educational method helped students achieve their learning goals through expressing their feelings, writing skills, creativity, emotions and opinions. Consistent with the results of Arslan (2013), Xu et al. (2011), Kulla-Abbott (2006), Green (2011), Kaya (2013), our participants found using Toondoo Comics very supportive to present their stories and poems as they could display their personal experiences in their own style. Consequently, creative activities and technology were main factors for students to become creative writers. Accordingly, the post questionnaire results highlighted these factors as major to increase our learners' motivation level, similar to Temizka (2011), Vanderslice (2011) and Mayers' (2009) our results indicated that creative writing tasks using Toondoo, implemented in the two taught courses, motivated our students in a way that $75 \%$ claimed that they will continue writing creative stories and poems after the intervention is stopped and that they will use it in their future teaching career in both teaching and learning processes . Finally, poems and stories as literary genres have the potential of providing a valuable resource that represents the structures of language authentic texts, which in turn can be considered as a model for students to practice language items in various written forms.

Therefore, and through all what was mentioned so far, it was encouraging to examine the impact of Toondoo Comics integrated in the English education courses on the Lebanese university student teachers' motivation, perceptions and creativity in writing poems and stories.

\section{CONCLUSION AND RECOMMENDATION}

\section{CONCLUSION}

The study is considered a qualitative quantitative one, and the research method adopted followed the assumptions and steps of the experimental approach of Cousin (2009). The results indicated that using Toondoo Comics as a creative teaching strategy can enhance students' writing skills, assist in the development of innovation and flexibility, and also contribute to reducing the gap between theory and practice.

As noted earlier, the aim of this study is to investigate the impact of integrating Toondoo Comics in Creative Writing and Children Literature courses taught at the Lebanese university faculty of Pedagogy on students' creative writing, motivation and attitude. Generally speaking, the students displayed positive attitudes towards teachingllearning the creative courses using Toondoo, as they highly appreciated experiencing this offered technique by their instructors. The study pinpointed the fact that teaching creative writing courses is efficient to improve students' reading and writing skills and strategies when practiced in an updated learning environment away from traditional teaching methods. The study proves by statistics that implementing technology in teaching creative writing courses encouraged students to participate, indulged in learning, and have better writing styles. Students attitude toward this technique of learning creative writing was positive as they expressed its 
benefits in developing their writing creativity, generating aesthetic language, and continuity to write. Thus, the study emphasizes the creative writing skills as one of the basic English education skills in teaching and learning that requires the right instruction with effective proficiency to guide students and help them improve their creative strategies, writing skills, critical thinking and reading skills. Moreover, the conducted technology technique in the creative courses, motivated students to develop their writing skills, writing strategies, reading strategies, analytical skills, synthesis skills and creativity in choosing the out of common expressions, ideas and aesthetic language to write creatively the different genres of literature. Similar to many mentioned researchers, the students made positive changes in their creative writing, which means that they could overcome their writing problems through practicing, discussing, and technology.

A straight forward implication of the findings is that creative writing teaching with the help of Technology can be a very productive and creative writing technique for university students. The different creative activities conducted in this study led students to develop deeper critical thinking that helped achieving better learning of the critical reading and writing strategies. Thus, implementing Toondoo Comics creative writing course fostered students write different genres of literatures in a creative way following the required elements and characteristics of each type. Furthermore, we can say that the process followed in this study emphasized writing creatively, where students expressed their own feelings, emotions, concepts, beliefs, understanding using creative aesthetic language structures to come up with creative stories and creative poems that they converted into comics. The process followed in this study paved the way for students to develop their writing skills and their attitude toward writing using technology. The success of this study lies in developing students' abilities to understand the importance of creative writing and of using technology in education learning and teaching processes that was reflected through the significant results of the post questionnaire and their written poems and stories. Finally, the present study indicates that the period of 13 weeks practicing creative writing helped increase our students English creative writing achievements and their attitude to the taught creative writing courses. These findings highlight the importance of focusing on the creative writing techniques using technology, rather than having only sessions guided by the traditional method classes. Not to forget that observation and discussions were of the central elements in teaching creative writing courses that encouraged students to interact with each other and gain new ideas, recognize their mistakes and develop communication as well as writing creatively. It is an aspect that needs special attention and instruction to provide students with effective technology proficiency. Thus, it is suggested that creative writing course instructors should be highly encouraged to provide the students with adequate instructions of writing creative literature genres before converting them into comics using Toondoo, and finding academic solutions to students bordom and avoidance of writing. It is hoped that this paper would offer instructors dealing with English education learners the suitable writing strategies, one of which, integrating Toondoo in creative writing course, which arises students ${ }^{\text {ee }}$ motivation.

\section{LIMITATIONS AND RECOMMENDATIONS}

Nevertheless, the limitations to over generalizing these findings should be avoided as the study is limited to two English education class students at the Lebanese university faculty of pedagogy branch two in Beirut Lebanon. Further studies are required to overcome the limitations of the present study and to produce more convincing evidence of the importance of focusing on technology usage in contexts of English education courses. Finally, it is hoped as well that this paper suggests a considerable addition to the existing literature as far as integrating technology in education are concerned.

\section{REFERENCES}

[1] Al-Hakeem, M. S., \& Abdulrahman, M. S. (2017) Developing a New e-Exam Platform to Enhance the University Academic Examinations: The Case of Lebanese French University. International Journal of Modern Education and Computer Science, Vol. 9 (5),

[2] Anastasiou, L. G. C., \& Alves, L. P. (Orgs.). (2004). Processo de ensinagem na universidade: pressupostos para as estratégias de trabalho em sala de aula (3a ed.). Joinville: Univille.

[3] Baranauckas et al. (2012) Daily Source Organization. Retrieved from http://www.dailysource.org/about/ impact\#.T4ri66waPpw. 
The Impact of Toondoo Comics on Undergraduate Students Taking Creative Writing and Children Literature Courses at the Lebanese University Faculty of Pedagogy

[4] Borba, A. M., \& Luz, S. P. (Coords.). (2002). Formação continuada para docentes do ensino superior: apontamentos para novas alternativas pedagógicas. Itajaí: UNIVALI.

[5] Boulos, M.N.,Maramba,I.,\&Wheeler,S. (2006).Wikis,blogsandpodcasts:a new generation of Web T based tools for virtual collaborative clinical practice and education. BMC medical education, 6 (1), 41.

[6] Brown, S. (2010). From VLEs to learning webs: the implications of Web 2.0 for learning and teaching. Interactive Learning Environments, 1 8(1), $1 \mathrm{~T} 10$.

[7] Bull, G., and Kajder, S. (2004). Digital story in the language arts classroom. Learning \& Leading with Technology, 32(4), 46-49.

[8] Calmorin, L. (2010) Research and Statistics. National Bookstore, Philippines.

[9] Carmichael, D., \& MacEachen, C. (2017) Heuristic Evaluation of the use of Blackboard \& Facebook Groups in Computing Higher Education. International Journal of Modern Education and Computer Science, Vol. 9 (6),

[10] Caruso, F., \& Freitas, N. (2009). Física moderna no ensino médio: o espaço tempo de Einstein em tirinhas. Caderno Brasileiro de Ensino de Física, 26(2), 355-366.

[11] Cousin, G. (2009). Research learning in higher education: an introduction to contemporary methods and approaches. New York: Routledge.

[12] Crook, C. (2008). Web 2.0 technologies for learning: The current landscape H opportunities, challenges and tensions: BECTA.

[13] Daniels, H. (2012). "Institutional Culture, Social Interaction and Learning." Learning, Culture and Social Interaction 1 (1): 2-11.

[14] Denovan, A., and A. Macaskill. (2013). “An Interpretative Phenomenological Analysis of Stress and Coping in First Year Undergraduates.” British Educational Research Journal 39 (6): 1002-24.

[15] Douglas, J., A. Douglas, R. McClelland, and J. Davies. (2015). "Understanding Student Satisfaction and Dissatisfaction: An Interpretive Study in the UK Higher Education Context." Studies in Higher Education 40 (2): 329-349.

[16] Eisner, W. (2010). Quadrinhos e arte sequencial: princípios e práticas do lendário cartunista (4a ed.). São Paulo: Martins Fontes.

[17] Entwistle, N., and P. Ramsden. (1983). Understanding Student Learning. London: Croom Helm.

[18] Fenwick, T. J. (2003). Learning through experience: troubling orthodoxies and intersecting questions. Florida: Krieger.

[19] Flores, M., A. Simão, A. Barros, and Pereira, D. (2014). "Perceptions of Effectiveness, Fairness and Feedback of Assessment Methods: A Study in Higher Education." Studies in Higher Education doi:10.1080/03075079.2014.881348.

[20] Franklin, T., \& Van Harmelen, M. (2007). Web 2.0 for content for learning and teaching in higher education. JISC www. jisc. ac. Uk/ media /documents/ programmes /digital repositories/web2H content learning and $\mathrm{H}$ teaching. pdf.

[21] Gale, T., and S. Parker. (2014). "Navigating Change.” Studies in Higher Education 39 (5): 734-53

[22] Gil, A. C. (2005). Metodologia do ensino superior (4a ed.). São Paulo: Atlas.

[23] Glaeser, B. C., Pierson, M. R., \& Fritschmann, N. (2003). Comic strips conversation: a positive behavioral support strategy. Teaching Exceptional Children, 36(2), 14-19.

[24] Gómez, A. P. (2011). Competências ou pensamento prático? A construção dos significados de representação e de ação. In J. G. Sacristán. Educar por Competências, o que há de novo? Porto Alegre: Artmed.

[25] González, Alba Milena Velandia. (2017) Comics in Toondoo and Collaborative learning, a visual literacy resource to evidence vocabulary learning with emphasis in action verbs in an EFL group of seventh graders. Retrieved from https://www.researchgate.net, 2016.

[26] Greenhow, C., Robelia, B., \& Hughes, J. E. (2009). Learning, teaching, and scholarship in a digital age Web 2.0 and classroom research: What path should we take now? Educational Researcher, 38 (4), $246 \mathrm{~T} 259$.

[27] Guimarães, E. (2001). História em quadrinhos como instrumento educacional. Anais do XXIV Congresso Brasileiro da Comunicação, Campo Grande, MS, 24, 1-16.

[28] International Society for Technology in Education (ISTE). (2008) Technology and Student Achievement - The Indelible Link,. Retrieved from http://www.k12hsn.org.

[29] Jenkins, M., and Lonsdale, J. (2007). Evaluating the effectiveness of digital story for student reflection. Proceedings ascilite, Singapore, 440-444. 
The Impact of Toondoo Comics on Undergraduate Students Taking Creative Writing and Children Literature Courses at the Lebanese University Faculty of Pedagogy

[30] Jensen, T. S., Voigt, J. R., Piras, E. R., \& Thorsen, B. R. (2007). Drawings as a link to emotional data: a slippery territory. In M. Reynolds \& R. Vince (Eds.). Experiential learning and management education. New York: Oxford University Press.

[31] Kahiigi, E. (2013) A Collaborative E-learning Approach Exploring a Peer Assignment Review Process at the University Level in Uganda. Retrieved on 3 November 2013 from http://su.diva-portal.org.,.

[32] Karber, D. J. (2001) Comparisons and Contrasts in Traditional Versus On-Line Teaching in Management. Higher Education In Europe, 26(4), 533-536,

[33] Kiliçkaya, F., \& Krajka, J. (2012). Can the use of web-based comic strip creation tool facilitate EFL learners' grammar and sentence writing? British Journal of Educational Technology, 43(6), 161-165.

[34] Kolb, D. A. (1984). Experiential learning: experience as the source of learning and development. New Jersey: Prentice Hall.

[35] Lairio, M., S. Puukari, and A. Kouvo. (2013). "Studying at University as Part of Student Life and Identity Construction." Scandinavian Journal of Educational Research 57 (2): 115-31.

[36] Lambert, J. (2010). Digital Story Cookbook. Berkley, CA: Digital Diner Press.

[37] Lambropoulos, N, Culwin, N and Romero, M. (2010) HCI Education to Support Collaborative e-Learning Systems Design.. Retrieved from http://elearnmag.acm.org/archive.cfm?aid=1858580

[38] Langer, J. (2009). O ensino de história medieval pelos quadrinhos. História, imagem e narrativas, (8), 124.

[39] Li, Lilian K.Y. (2012) A Study of the Attitude, Self-efficacy, Effort and Academic Achievement of City U Students towards Research Methods and Statistics. Discovery - SS Student E-Journal.

[40] Liaw, Shu-Sheng and Huang, Hsiu-Mei. (2011) A Study of Investigating Learners' Attitudes Toward ELearning. 5th International Conference on Distance Learning and Education vol.12, Singapore.

[41] Lima, M. C., \& Silva, C. C. S. (2014). Professores como designers educacionais. Anais do Encontro da Associação Nacional de Pós-Graduação e Pesquisa em Administração (Anpad), Rio de Janeiro, RJ, 38, 116.

[42] Lima, T. B. (2011). Estratégias de ensino balizadas pela aprendizagem em ação: um estudo de caso no curso de graduação em administração da Universidade Federal da Paraíba. Dissertação de mestrado, Universidade Federal da Paraíba, João Pessoa, PB, Brasil.

[43] Lowman, J. (2004). Dominando as técnicas de ensino. São Paulo: Atlas.

[44] Lu, Lai-Chen and Yeh, Ching-Long (2008). Collaborative ELearning Using Semantic Course Blog Volume 6, Issue 3.

[45] Macaskill, A., and A. Denovan. (2013). "Developing Autonomous Learning in First Year University Students Using Perspectives from Positive Psychology.” Studies in Higher Education 38 (1): 124-42.

[46] Mackenzie, (Mackenzie Management Review), 18(1), 40-65 (2017) ISSN 1678-6971 (electronic version) • http://dx.doi.org/10.1590/1678-69712017/ administracao. v. 18, n1 p 40-65 48. Anielson Barbosa da Silva, Gabriela Tavares dos Santos e Ana Carolina Kruta de Araújo Bispo https: // en . m . wikibooks. org/ wiki/ Web 2.0 and Emerging Learning Technologies/ Toondoo

[47] Malhiwsky, Dallas R. (2011) "Student Achievement Using Web 2.0 Technologies: A Mixed Methods Study". Open Access Theses and Dissertations from the College of Education and Human Sciences. Paper 58. Retrieved from http://digitalcommons.unl.edu/cehsdiss/58.

[48] Marquadt, M. J., Leonard, H. S., Freedman, A. M., \& Hill, C. C. (2009). Action learning for development leaders and organizations: principles, strategies and cases. Washington: American Psychological Association.

[49] Masetto, M. T. (2012). Competência pedagógica do professor universitário. (2a ed.). São Paulo: Summus.

[50] Matt, B. (2015) A Typology of Web 2.0 Learning Technologies. Macquarie University, Sydney, Australia.

[51] McGill, I., \& Brockbank, A. (2004). The action learning handbook: powerful techniques for education, professional development and training. New York: Routledge.

[52] Merriam, S. B., \& Bierema, L. L. (2014). Adult learning: linking theory and practice. San Francisco: Jossey-Bass.

[53] Ohler, J. B. (2008). Digital Story in the Classroom: New Media Pathways to Literacy, Learning, and Creativity. California: Corwin Press.

[54] Oliveira, R. M. (2014). Aprendizagem experiencial: problem-based learning como estratégia de ensino: diagnóstico para a aplicabilidade no curso de ciências contábeis da Universidade Federal do Paraná. Dissertação de mestrado, Universidade Federal do Paraná, Curitiba, PR, Brasil. 
The Impact of Toondoo Comics on Undergraduate Students Taking Creative Writing and Children Literature Courses at the Lebanese University Faculty of Pedagogy

[55] Palmer, M., G. Simmons, and M. Hall. (2013). "Textbook (Non-)adoption Motives, Legitimizing Strategies and Academic Field Configuration." Studies in Higher Education 38 (4): 485-505.

[56] Pimenta, S. G., \& Anastasiou, L. G. C. (2010). Docência no ensino superior. São Paulo: Cortez.

[57] Portugal, C. (2016) Digital Games and Interactive Activities: Design of Experiences to Enhance Children Teaching Learning Process. International Journal of Modern Education and Computer Science, 8 (12), 1.

[58] Psaltou-Joycey, A., and Z. Kantaridou. (2011). "Major, Minor, and Negative Learning Style Preferences of University Students.” System 39 (1): 103-12.

[59] Pund, M. (2013). New Factors Impact Stress in College Students. Northerner Online. Retrieved on 5 December 2013 from http://www.thenortherner.com/news/2013/02/28/newfactors-impact-stress-incollege-students/.

[60] Raelin, J. A. (2009). Action learning and related modalities. In S. J. Armstrong \& C. V. Fukami. The SAGE handbook of management learning, education and development. London: Sage.

[61] RAM, REV. ADM. MACKENZIE (Mackenzie Management Review), 18(1), 40-65 • SÃO PAULO, SP • JAN./FEB. (2017) ISSN 1678-6971 (electronic version) • http://dx.doi.org/10.1590/1678-69712017/ administracao.v18n1p40-65 47

[62] Ramos, P. (2006). É possível ensinar oralidade usando histórias em quadrinhos?. Revista Intercâmbio, XV, São Paulo, LAEL/PUC-SP.

[63] Rebolho, M. C. T., Casarotto, R. A., \& João, S. M. A. (2009). Estratégias para ensino de hábitos posturais em crianças: história em quadrinhos versus experiência prática. Fisioterapia e Pesquisa, 16(1), $46-51$.

[64] Redecker, C., Ala T Mutka, K., Bacigalupo, M., Ferrari, A., \& Punie, Y. (2009). Learning 2.0: The impact of Web 2.0 innovations on education and training in Europe. Final Report. European Commission H Joint Research Center H Institute for Prospective Technological Studies, Seville.Commission on Higher Education (CHED) Memorandum Order No 46.

[65] Robin, B. R., \& Pierson, M. E. (2005). A multilevel approach to using digital story in the classroom. Paper presented at the annual meeting of the Society for Information Technology \& Teacher Education, Phoenix, AZ.

[66] Robins, B. (2008). The educational uses of digital story - Getting started. Retrieved from http://digitalstory. coe.uh.edu/getting_started.html David B. Kent (Graduate School of TESOL-MALL, Woosong University) dbkent@wsu.ac.kr

[67] Robles, Ava Clare Marie O. (2010). The Use of Educational Web Tools: An Innovative Technique in Teacher Education Courses. I.J.Modern Education and Computer Science, 1-7 Published Online November 2010 in MECS (http://www.mecs-press.org/).

[68] Rossetto, M., \& Chiera-Macchia, A. (2011). Visual learning is the best learning-it lets you be creative while learning: exploring ways to begin guided writing in second language learning through the use of Comics. Babel, 45(2-3), 35-40.

[69] Salmons, J. (2013). Story \& Collaborative E-Learning Resources for Educators. Retrieved from http://www.vision2lead.com/Story.pdf

[70] Sangameswar, M. V., Rao, M. N., \& Kumar, M. S. (2017) Building a Natural Disaster Management System based on Blogging Platforms. International Journal of Modern Education and Computer Science, Vol. 9 (8).

[71] Santos, G. T. (2013). Aprendizagem experiencial: um estudo com acadêmicos dos cursos de administração do estado da Paraíba. Dissertação de mestrado, Universidade Federal da Paraíba, João Pessoa, PB.

[72] Schön, D. A. (2000). Educando o profissional reflexivo: um novo design para o ensino e a aprendizagem. Porto Alegre: Artmed .

[73] Selwyn, N. (2014). Digital Technology and the Contemporary University. London: Routledge.

[74] Silva, A. B. (2009). Como os gerentes aprendem? São Paulo: Saraiva.

[75] Silva, A. B. (2014). Reflexões teórico-práticas de um sistema de aprendizagem-em-ação para a educação em administração. Anais do Encontro da Associação Nacional de Pós-Graduação e Pesquisa em Administração (Anpad), 1, Rio de Janeiro, RJ, 38, 1-12.

[76] Silva, A. B. (2016). Action learning: lecturers, learners, and managers at the Center of Management Education. In: M. T. Lepeley, E. V. Kimakovitz \& B. Roland (Orgs.). Human Centered Management in Executive Education: Global Imperatives, Innovation and New Directions. (pp. 126-139). London: Palgrave Macmillan.

[77] Silva, A. B., Lima, T. B., Sonaglio, A. L. B., \& Godoi, C. K. (2012). Dimensões de um sistema de aprendiza- gem em ação para o ensino de administração. Administração: Ensino e Pesquisa, 13(1), 9-41. 
The Impact of Toondoo Comics on Undergraduate Students Taking Creative Writing and Children Literature Courses at the Lebanese University Faculty of Pedagogy

[78] Snyder, E. (1997). Teaching the sociology of sport: using a comic strip in the classroom. Teaching Sociology, 25(3), 239-243.

[79] Souza, C. S., Iglesias, A. G., \& Pazin-Filho, A. (2014). Estratégias inovadoras para métodos de ensino tradicionais - aspectos gerais. Medicina, 43(3), 284-292.

[80] Stokoe, E., B. Benwell, and F. Attenborough. (2013). "University Students Managing Engagement, Preparation, Knowledge and Achievement.” Learning, Culture and Social Interaction 2 (2): 75-90.

[81] Su, Feng and Beaumont, Chris. (2010). Evaluating the use of a wiki for collaborative learning. Retrieved 25 December 2013 from http://repository.edgehill.ac.uk,.

[82] Tedre, M., Ngumbuke, F., \& Kemppainen, J. (2010). Infrastructure, human capacity, and high hopes: A decade of development of e-learning in a Tanzanian HEI. Revista de Universidad y Sociedad del Conocimiento, 7(1), 7-20.

[83] Unwin, T. ICT4D (2009). Information and communication technology for development. Cambridge University Press, Cambridge, UK,

[84] Virtanen, V., and S. Lindblom-Ylänne. (2010). “University Students' and Teachers' Conceptions of Teaching and Learning in the Biosciences.” Instructional Science 38 (4): 355-70.

[85] Wilujenga , N. C. S., \& ju LAN, Y. (2013) Online cartoon in Mandarin Chinese teaching: A case study of a school in Indonesia,.

[86] Wood Jr., T. (2008). Filmes de longa-metragem na sala de aula (Relatório de Pesquisa). São Paulo: GV Pesquisa.

[87] Woodall, T., A. Hiller, and S. Resnick. (2014). "Making Sense of Higher Education." Studies in Higher Education 39 (1): 48-67.

[88] Wright, F., D. White, T. Hirst, and A. Cann. (2014). "Visitors and Residents." Learning, Media and Technology 39 (1): 126-41.

[89] Wurdinger, S. D., \& Carlson, J. A. (2010). Teaching form experiential learning: five approaches that work. United Kingdom: Rowman \& Littlefield Publishers. Received: January 10, 2016; Accepted: June 26, 2016

[90] Yasemin Kırkgöz (2014). Procedia - Social and Behavioral Sciences 158394 - 401.

\section{AUTHORS' BIOGRAPHY}

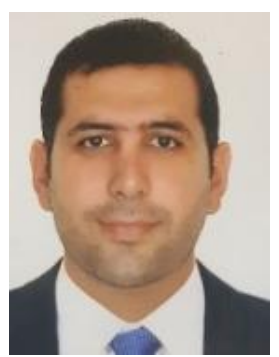

Charbel Y. Semaan, was born on May 20, 1981, in El Haouch, Lebanon. He graduated from Notre Dame University (Lebanon) with a Bachelor of Science degree in Business Computing in 2005. Then, he graduated with a Master degree in Business Administration from Notre Dame University (Lebanon), and a Master of Sciences in International Business from Bordeaux Business School (France). In 2013, He got his Educational Doctorate Degree in educational leadership (EDD) from Saint Louis University (USA). He is an instructor at the Lebanese University, Faculty of Education, since 2009.

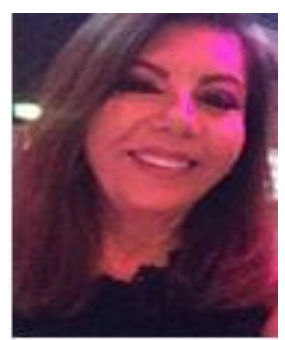

Mona M. Tahseldar, was born on June 1st, 1955 in Tripoli Lebanon. She got her English education MA in 1994 and PHD in 2007 from USJ University. Mona is an associate professor at the Lebanese University, faculty of education since 2006.

Citation: Mona Tahsaldar, Charbel Semaan "The Impact of Toondoo Comics on Undergraduate Students Taking Creative Writing and Children Literature Courses at the Lebanese University Faculty of Pedagogy" International Journal of Humanities Social Sciences and Education (IJHSSE), vol 5, no. 8, 2018, pp. $203-226$ doi: http://dx.doi.org/10.20431/2349-0381.05080019.

Copyright: (C) 2018 Authors. This is an open-access article distributed under the terms of the Creative Commons Attribution License, which permits unrestricted use, distribution, and reproduction in any medium, provided the original author and source are credited. 